\title{
Corrosion of Nickel Cast Irons in Soils
}

\author{
Irving A. Denison and Melvin Romanoff
}

\begin{abstract}
The results of measurements of the corrosion and of the strength of nickel cast irons after exposure to different soil conditions for a maximum of 14 years are reported. The magnitude and progress of corrosion, as determined by weight-loss and pit-depth measurements, are correlated with the composition of the materials and the nature of the environmental conditions to which the specimens were exposed. The residual strength of the corroded cast iron that had been removed from the more corrosive soils was evaluated by subjecting the pipe specimens to hydraulic pressures up to $500 \mathrm{lb} / \mathrm{in}^{2}$.
\end{abstract}

\section{Introduction}

Corrosion of cast iron in soils is characterized by the development of an adherent layer of corrosion products that increases in thickness as corrosion progresses. The thickening of this layer is due in part to electrochemical action between the ferritic and graphitic constituents of cast iron and partly to differences in potential that arise from contact of the cast metal with the soil, as, for example, by differential aeration. To the extent that corrosion of cast iron is caused by differences in potential within the metal itself, improved corrosion resistance would be expected to result from improvement in the quality of the casting. Wesley, Copson, and LaQue [1] ${ }^{1}$ have shown that the addition of small amounts of nickel and nickel plus chromium alters the structure of cast iron in such manner that galvanic action between the different constituents is reduced considerably. Larger additions of these alloying elements in amounts sufficient to produce an austenitic structure were shown to be considerably more effective in reducing corrosion under the experimental conditions because of the ennobling effect of nickel and chromium on the potential of iron.

In order to evaluate the effect of additions of nickel and of nickel plus chromium on the corrosion of cast iron in soils, samples of alloy cast irons were included in an extensive series of exposure tests of materials for underground construction. In 1932, samples of a high-alloy austenitic cast-iron pipe were buried at 15 test sites, and in 1941 samples of several low-alloy cast irons were buried at 13 of the same test sites, and at 1 other site. In a previous report [2], corrosion data were reported for five periods of exposure for the samples of high-alloy cast iron and for a single period for the samples of low-alloy cast irons. With the completion of the exposure tests in 1952, data for the latter materials became available for four periods of exposure, with a maximum exposure of 11 years.

After removal of the samples from the test sites, the procedure followed during the early periods of the exposure program was to clean the samples of all corrosion products preparatory to measuring the weight losses and the depths of the deepest pits. This pro-

\footnotetext{
1 Figures in brackets refer to literature references at the end of this paper.
}

cedure was later modified by subjecting those samples in the form of pipe to hydraulic pressure before re-moval of the corrosion products. This modification was introduced in order to evaluate the strength of the corrosion products remaining in the pits of the samples that had been perforated by corrosion. The methods used for cleaning the corroded samples and for measuring the depth of pitting have been previously described [3].

\section{Properties of the Soils at the Test Sites}

The location of the test sites, the identification of the soil types, and the properties of the soils that are associated with corrosion are given in table 1 . The retentiveness of the soils for water is indicated by the values for moisture equivalent, which is the quantity of water retained by a previously saturated soil against a centrifugal force of 1,000 times gravity. Because the real specific gravities of rock-forming: minerals lie within a narrow range, values for apparent specific gravity are an index of the relative compactness or porosity of inorganic soils.

\section{Description of the Materials}

The forms, dimensions, and compositions of the specimens are given in table 2 . The ends of the pipes were closed with cast-iron screw caps of the same composition as the specimens in order to exclude moisture from the interior. As an extra precaution against internal corrosion, the interior surface of the specimens was coated with heary grease.

\section{Weight Losses and Maximum Pitting}

The data of table 3 indicate that the high-alloy cast iron $\mathrm{E}$ was considerably more resistant to corrosion, as measured by both weight loss and maximum pitting, than either the plain cast iron $\mathrm{A}$ or the low-alloy cast irons B, C, D, NC, and N. It is noteworthy that, except in cinders, the deepest pit measured on the specimens of material $\mathrm{E}$ in more than 14 years of exposure was only 74 mils.

The effect of composition on the corrosion of the low-alloy cast irons can be observed to somewhat better advantage by calculating the weight losses of 
these specimens on a relative basis. This would have the effect of eliminating the differences in corrosivity of the soils due to differential aeration and emphasizing the effect of graphitic corrosion. In table 4 the weight losses of materials $B, C$, and D are shown for each soil and for each period of exposure relative to the plain cast iron A. Except for the well-drained soils of high resistivity (soils 53, 55, and 62), and soil 66 , in which accelerated corrosion of the alloy cast irons occurred, the relative weight losses of the specimens during the initial period of exposure is seen to have decreased with increasing content of nickel. For example, during the first period of 5 years' duration the weight losses of material D in soils 58 and 63 were only 20 and 16 percent, respectively, of the weight losses of plain cast iron in the same soils for the same period. However, this initial advantage from the addition of nickel was usually not maintained, with the result that the weight losses of the alloy cast irons exposed for the maximum period usually did not differ greatly from the losses of plain cast iron. Hence, it would appear that the rates of corrosion of the alloys containing the higher amounts of nickel decrease less with time than do the rates for the alloys containing the lower amounts of nickel and plain cast iron.

\section{Strength of Corroded Cast-Iron Pipe}

Corrosion of cast iron in soils is characterized by the conversion of the metal into a layer consisting chiefly of oxides of iron and graphite. Although the original shape and appearance of the metal are retained, visual observation gives no indication of the extent of corrosion (fig. 1). It is generally recognized that corroded cast iron retains some of its original strength, but the extent to which cast-iron pipe may corrode underground and still retain sufficient strength to withstand the pressures commonly used in water- and gas-distribution systems has not previously been estimated.

In order to evaluate the residual strength of corroded cast-iron pipe, the samples of pipe that had been removed from the more corrosive soils after the longer periods of exposure were subjected to hydraulic pressures. The screwcap on one end of each sample was replaced by a similar cap in which a fitting had been inserted and the pipe section connected by copper tubing to a hand pump of suitable capacity. The pressure was increased at the rate of approximately $10\left(\mathrm{lb} / \mathrm{in} .^{2}\right) / \mathrm{sec}$ until failure of the pipe occurred or the maximum pressure of 500 $\mathrm{lb} / \mathrm{in}^{2}$ was attained. After the application of hydraulic pressure, the corrosion products were removed, and the condition of the specimens was evaluated in the usual manner. The hydraulic pressures applied to the samples and the number of perforations in the samples after being cleaned are given in table 5.

The data in table 5 show that most of the specimens withstood a maximum presssure of $500 \mathrm{lb} / \mathrm{in}^{2}$, although removal of the corrosion products revealed numerous holes of various diameters. The few low values of bursting pressure given in the table probably should not be taken as accurately measuring the strength of the corroded pipe because of oxidation and probable damage to the pipe in handling and shipping. Hence it is reasonable to conclude that cast-iron pipe in an advanced stage of graphitic corrosion is able to withstand the minimum pressure required of class 150 pipe.

In considering the data of table 5 , it is important to note that the pipe samples were subjected to hydraulic pressure from 6 months to a year after removal from the test sites. Inspection of the samples showed that during this interval some oxidation of the corrosion products occurred, as was indicated by slight increase in the volume of the corrosion products. Because oxidation is associated with loss in strength, it is reasonable to assume that if the samples had not been removed from the test sites, they would have withstood the applied pressure, even if they had been in a more advanced stage of corrosion. Instances of the loss in strength of graphitized cast-iron objects on exposure to air have been cited by Speller [4].

In order to evaluate the strength of the corrosion products of cast-iron pipe undisturbed by removal from the test sites, 3 -ft sections of 6 -in. cast-iron pipe, closed at both ends, were buried at 4 of the Bureau test sites. The investigation was undertaken with the cooperation of the Cast Iron Pipe Research Association. Provision was made for applying hydraulic pressure to the pipe sections by means of a fitting inserted in the closure at one end of the pipe. According to the plan of the test, a pressure of $400 \mathrm{lb} / \mathrm{in}^{2}$ is applied to the pipe sections at approximately 2 -year intervals until rupture occurs, at which time the section will be removed and the extent of corrosion evaluated. As none of the pipe sections has failed as yet to withstand the applied pressure, the test is necessarily incomplete. However, the data obtained to date in certain of the soils provide significant information on the strength of corroded cast-iron pipe under normal conditions of exposure.

In table 6 are shown the number of years during which the pipe sections have withstood the applied pressure. For comparison, the condition of similarly exposed specimens of cast-iron pipe, as indicated by the maximum and average penetration, is also shown. The data reported for site 70 is especially significant. Although 1 of the control specimens was perforated within 6 years, the $3-\mathrm{ft}$ section has withstood the applied pressure for 24 years, during which time it would be expected to be converted almost entirely to corrosion products. Similarly, the development of a pit 302 mils in depth in 6 years on the control specimens in soil 118 indicates that the 3 - $\mathrm{ft}$ section, which withstood the applied pressure after 24 years of exposure, should also be in an advanced stage of corrosion.

\section{Summary}

This report contains the results of measurements of weight loss, maximum depth of pitting, and of 
hydraulic bursting pressure made on samples of nickel cast irons after exposure to different soil conditions. Additions of nickel up to 3 percent significantly reduced the initial corrosion of cast iron in poorly drained soils of low resistivity, but this advantage was not maintained for the duration of the exposure tests. Samples of austenitic cast iron containing 15 percent of nickel, together with chromium and copper, showed good resistance to corrosion in most of the soils, especially with respect to maximum depth of pitting.

With some exceptions, samples of severely corroded plain and low-alloy cast-iron pipe withstood a maximum hydraulic pressure of $500 \mathrm{lb} / \mathrm{in}^{2}{ }^{2}$ after exposure at the test sites for periods up to 11 years and storage in the laboratory for approximately 1 year. Because the effect of oxidation in the air is to weaken the layer of corrosion products, the observed values for hydraulic bursting pressure are probably to be considered minimum values. The results of incomplete field tests of the bursting pressure of undisturbed sections of plain cast-iron pipe are in good agreement with the results of the measurements made on the stored samples.

The direction of this program by Mr. K. H. Logan prior to his retirement in 1946 is acknowledged.

\section{References}

1] W. A. Wesley, H. R. Copson, and F. L. LaQue, Metals \& Alloys 7,325 (1936).

[2] Irving A. Denison and Melvin Romanoff, J. Research NBS 44, 47 (1950) RP2057.

[3] Kirk H. Logan, Underground corrosion, NBS Circular 450 (1945).

[4] F. N. Speller, Corrosion, causes and prevention (MeGrawHill Book Co., New York, N. Y., 1951).

TABLE 1. Properties of the soils at the test sites

\begin{tabular}{|c|c|c|c|c|c|c|c|c|c|c|c|c|c|c|c|}
\hline \multicolumn{3}{|c|}{ Test sites } & \multirow[b]{2}{*}{$\begin{array}{l}\text { Aera- } \\
\text { tion }\end{array}$} & \multirow{2}{*}{$\begin{array}{l}\text { Mois- } \\
\text { ture } \\
\text { equiv- } \\
\text { alent }\end{array}$} & \multirow{2}{*}{$\begin{array}{l}\text { Appar- } \\
\text { ent } \\
\text { specific } \\
\text { gravity }\end{array}$} & \multirow{2}{*}{$\begin{array}{c}\text { Resis- } \\
\text { tivity at } \\
60^{\circ} \mathrm{F} \\
\left(15.6^{\circ}\right. \\
\mathrm{C})\end{array}$} & \multirow{2}{*}{$\mathrm{pH}$} & \multirow{2}{*}{$\begin{array}{c}\text { Total } \\
\text { acidityb } \\
\text { (milli- } \\
\text { gram } \\
\text { equiv- } \\
\text { alent } \\
\text { per } 100 \\
\text { g of soil) }\end{array}$} & \multicolumn{7}{|c|}{$\begin{array}{l}\text { Composition of water extract (milligram equivalent per } \\
\qquad 100 \mathrm{~g} \text { of soil) }\end{array}$} \\
\hline $\begin{array}{l}\text { Environment and } \\
\text { soil type }\end{array}$ & Soil & Location & & & & & & & $\begin{array}{r}\mathrm{Na}+\mathrm{K} \\
\text { as } \mathrm{Na}\end{array}$ & $\mathrm{Ca}$ & $\mathrm{Mg}$ & $\mathrm{CO}_{3}$ & $\mathrm{HCO}_{3}$ & $\mathrm{Cl}$ & $\mathrm{SO}_{4}$ \\
\hline \multicolumn{16}{|c|}{ INORGANIC OXIDIZING SOILS } \\
\hline $\begin{array}{l}\text { Cecil clay loam } \\
\text { Hagerstown loam.-. } \\
\text { Susquehanna clay.- } \\
\text { Chino silt loam.... } \\
\text { Mohave fine grav- } \\
\text { elly loam. }\end{array}$ & $\begin{array}{l}53 \\
55 \\
62 \\
65 \\
66\end{array}$ & $\begin{array}{l}\text { Atlanta, Ga } \\
\text { Loch Raven, Md.... } \\
\text { Meridian, Miss.-... } \\
\text { Wilmington, Califf.-. } \\
\text { Phoenix, Ariz...... }\end{array}$ & $\begin{array}{l}G \\
G \\
F \\
G \\
F\end{array}$ & $\begin{array}{c}\text { Percent } \\
33.7 \\
32.0 \\
34.6 \\
26.4 \\
16.5\end{array}$ & $\begin{array}{l}\text { 1. } 60 \\
\text { 1. } 49 \\
\text { 1. } 79 \\
\text { 1. } 41 \\
\text { 1. } 79\end{array}$ & \begin{tabular}{|c|} 
Ohm-cm \\
17,800 \\
5,210 \\
6,920 \\
148 \\
232
\end{tabular} & $\begin{array}{l}4.8 \\
5.8 \\
4.5 \\
8.0 \\
8.0\end{array}$ & $\begin{array}{r}5.1 \\
10.9 \\
12.0 \\
\mathrm{~A} \\
\mathrm{~A}\end{array}$ & $\begin{array}{l}-\cdots \\
\cdots-. \\
-7.65 \\
6.55\end{array}$ & $\begin{array}{r}-. . \\
12.40 \\
0.51\end{array}$ & $\begin{array}{l}\cdots \\
\cdots \\
2 . \\
0.18\end{array}$ & $\begin{array}{r}\cdots \\
\cdots .00 \\
0.00\end{array}$ & $\begin{array}{l}\cdots \\
\cdots \\
0.73\end{array}$ & $\begin{array}{l}-.- \\
6.05 \\
2.77\end{array}$ & $\begin{array}{r}16.90 \\
2.97\end{array}$ \\
\hline \multicolumn{16}{|c|}{ INORGANIC REDUCING SOILS } \\
\hline $\begin{array}{l}\text { Sharkey clay } \\
\text { Docas clay } \\
\text { Lake Charles clay.- } \\
\text { Merced silt loam }\end{array}$ & $\begin{array}{l}61 \\
64 \\
56 \\
70\end{array}$ & $\begin{array}{l}\text { New Orleans, La... } \\
\text { Cholame, Calif... } \\
\text { E1 Vista, Tex } \\
\text { Buttonwillow, Calif. }\end{array}$ & $\begin{array}{c}\mathrm{P} \\
\mathrm{F} \\
\mathrm{VP} \\
\mathrm{F}\end{array}$ & $\begin{array}{l}30.8 \\
41.1 \\
28.7 \\
24.7\end{array}$ & $\begin{array}{l}\text { 1. } 78 \\
\text { 1. } 88 \\
\text { 2. } 03 \\
\text { 1. } 69\end{array}$ & $\begin{array}{r}943 \\
62 \\
406 \\
278\end{array}$ & $\begin{array}{l}6.8 \\
7.5 \\
7.1 \\
9.4\end{array}$ & $\begin{array}{c}4.9 \\
\mathbf{A}^{5.1} \\
\mathbf{A}\end{array}$ & $\begin{array}{r}0.73 \\
28.10 \\
3.12 \\
8.38\end{array}$ & $\begin{array}{r}0.63 \\
2.29 \\
0.69 \\
.38\end{array}$ & $\begin{array}{r}0.33 \\
.76 \\
.47 \\
.22\end{array}$ & $\begin{array}{r}0.00 \\
.00 \\
.00 \\
.02\end{array}$ & $\begin{array}{r}0.71 \\
.89 \\
.80 \\
1.87\end{array}$ & $\begin{array}{r}0.10 \\
28.80 \\
1.59 \\
1.12\end{array}$ & $\begin{array}{r}0.91 \\
.26 \\
3.04 \\
5.57\end{array}$ \\
\hline \multicolumn{16}{|c|}{ ORGANIC REDUCING SOILS } \\
\hline $\begin{array}{l}\text { Carlisle muck } \\
\text { Muck } \\
\text { Rifle peat. } \\
\text { Tidal marsh }\end{array}$ & $\begin{array}{l}59 \\
58 \\
60 \\
63\end{array}$ & $\begin{array}{l}\text { Kalamazoo, Mich } \\
\text { New Orleans, La } \\
\text { Plymouth, Ohio.... } \\
\text { Charleston, S. C.... }\end{array}$ & $\begin{array}{l}\text { VP } \\
\stackrel{P}{P} \\
\stackrel{P}{V P}\end{array}$ & $\begin{array}{l}43.6 \\
57.8 \\
43.4 \\
46.7\end{array}$ & $\begin{array}{l}1.43 \\
1.28 \\
1.47\end{array}$ & $\begin{array}{r}1,660 \\
712 \\
218 \\
84\end{array}$ & $\begin{array}{l}5.6 \\
4.8 \\
2.6 \\
6.9\end{array}$ & $\begin{array}{r}12.6 \\
15.0 \\
297.4 \\
14.6\end{array}$ & $\begin{array}{r}1.03 \\
2.03 \\
23.91 \\
33.60\end{array}$ & $\begin{array}{r}3.08 \\
2.23 \\
10.95 \\
6.85\end{array}$ & $\begin{array}{l}\text { 2. } 70 \\
\text { 1. } 29 \\
\text { 2. } 86 \\
\text { 4. } 00\end{array}$ & $\begin{array}{r}0.00 \\
.00 \\
.00 \\
.00\end{array}$ & $\begin{array}{r}0.00 \\
.00 \\
.00 \\
.00\end{array}$ & $\begin{array}{r}3.47 \\
0.47 \\
.00 \\
12.70\end{array}$ & $\begin{array}{r}\text { 1. } 04 \\
2.54 \\
56.70 \\
3660\end{array}$ \\
\hline \multicolumn{16}{|c|}{ CINDERS } \\
\hline Cinders... & 67 & Milwaukee, Wis...... & VP & -... & -... & 455 & 7.6 & A & 0.77 & 3. 03 & 0.53 & .00 & .55 & 0.08 & 2.89 \\
\hline
\end{tabular}

s G, good; F, fair: P, poor, VP, very poor.

b $A$, alkaline reaction.

TABLE 2. Composition of the materials

\begin{tabular}{|c|c|c|c|c|c|c|c|c|c|c|c|c|}
\hline Material & $\begin{array}{l}\text { Identi- } \\
\text { fica- } \\
\text { tion }\end{array}$ & Form & $\begin{array}{l}\text { Nominal } \\
\text { Width } \\
\text { or Di- } \\
\text { ameter }\end{array}$ & I.ength & $\begin{array}{l}\text { Thick- } \\
\text { ness }\end{array}$ & $\underset{\text { (total) }}{\mathrm{C}}$ & $\mathrm{Si}$ & $\mathrm{Mn}$ & $\mathrm{S}$ & $\mathrm{Cr}$ & $\mathrm{Ni}$ & $\mathrm{Cu}$ \\
\hline $\begin{array}{l}\text { Plain cast iron } \\
\text { Low-alloy cast iron } \\
\text { Do } \\
\text { Do } \\
\text { Do } \\
\text { Do........... } \\
\text { High-alloy cast iron... }\end{array}$ & $\begin{array}{l}\mathrm{A} \\
\mathrm{B} \\
\mathrm{C} \\
\mathrm{NC} \\
\mathrm{N} \\
\mathrm{D} \\
\mathrm{E}\end{array}$ & \begin{tabular}{l} 
Pipe \\
\hdashline do \\
Plate \\
Pipe do \\
\end{tabular} & $\begin{array}{l}\text { in. } \\
\text { 1.5 } \\
\text { 1.5 } \\
1.5 \\
2.5 \\
2.5 \\
1.5 \\
1.5\end{array}$ & $\begin{array}{l}\text { in. } \\
13 \\
13 \\
13 \\
14 \\
14 \\
13 \\
10\end{array}$ & $\begin{array}{l}\text { in. } \\
0.250 \\
.250 \\
.250 \\
.5 \\
.5 \\
.250 \\
.250\end{array}$ & $\begin{array}{l}\% \\
3.22 \\
3.28 \\
3.24 \\
2.80 \\
2.75 \\
3.21 \\
2.98\end{array}$ & $\begin{array}{l}\% \\
2.19 \\
2.09 \\
2.08 \\
2.03 \\
2.00 \\
2.11 \\
2.13\end{array}$ & $\begin{array}{c}\% \\
0.91 \\
.83 \\
.80 \\
-. .- \\
-.72 \\
1.00\end{array}$ & $\begin{array}{r}\% \\
0.12 \\
.12 \\
.12 \\
-1 .- \\
.12 \\
-1 .-\end{array}$ & $\begin{array}{l}\% \\
-. \\
-.- \\
2 . \\
21\end{array}$ & \begin{tabular}{r}
$\%$ \\
\hdashline 1.27 \\
1.71 \\
2.08 \\
3.10 \\
3.32 \\
15.00
\end{tabular} & $\begin{array}{r}\% \\
0.32 \\
.98 \\
1.10 \\
-. . \\
6.58\end{array}$ \\
\hline
\end{tabular}


TABLE 3. Losses in weight and maximum pitting of plain and alloy cast irons

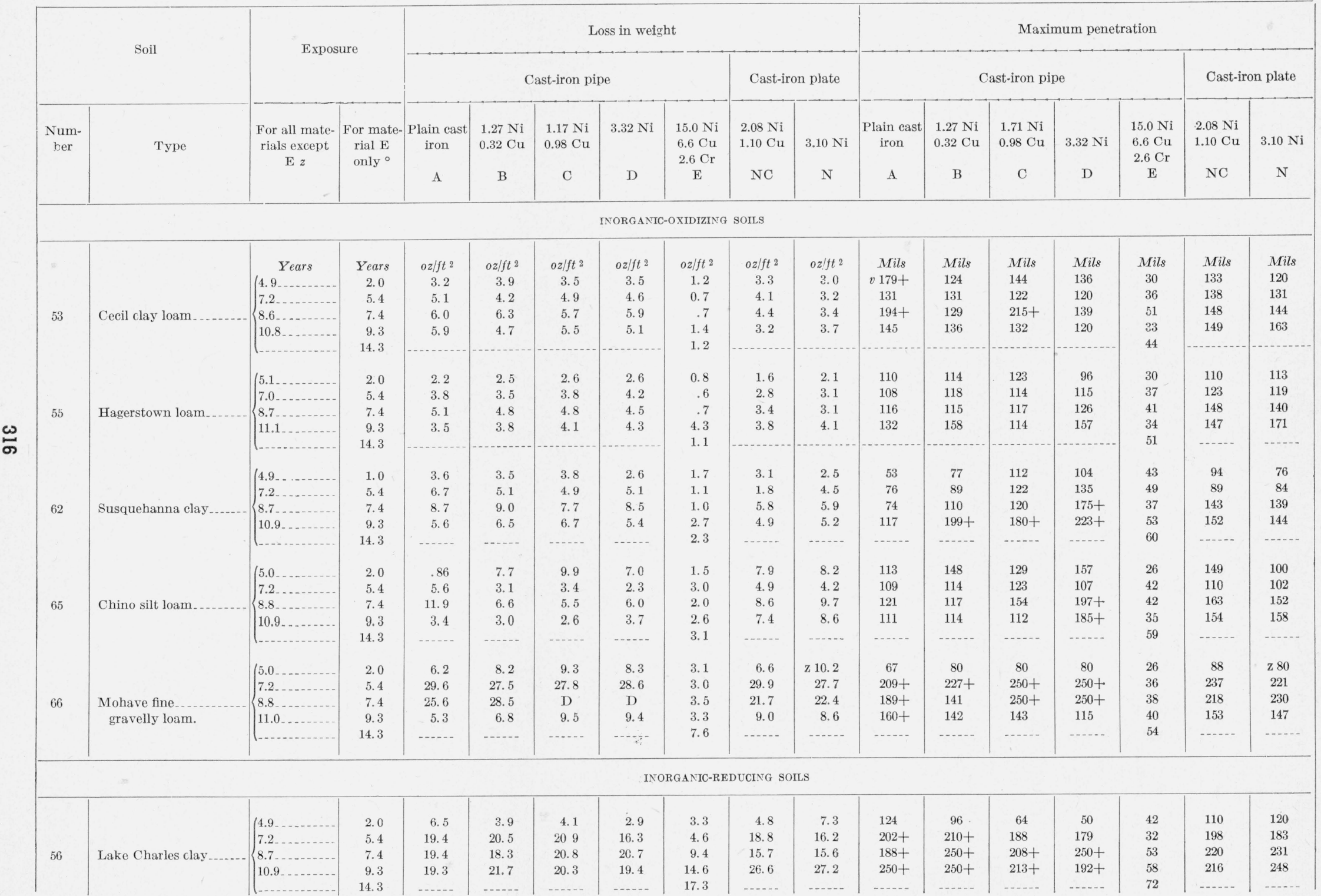




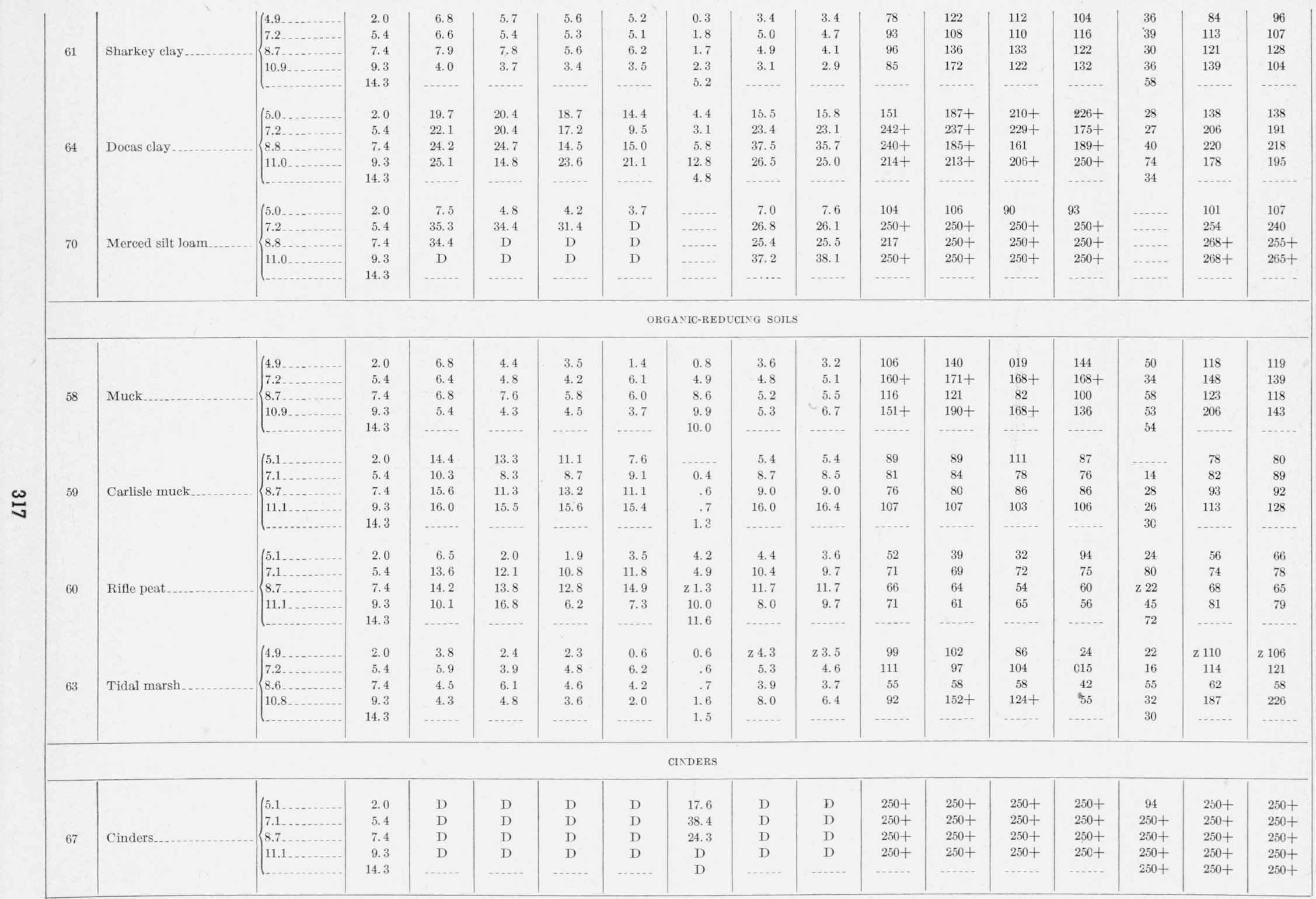

A verage of 2 specimens removed at each of the 5- and 9-year periods. d Data for 1 specimen only. The other specimen was missing. A verage of 3 specimens removed at each of the 7-and 11-year petiods. D D, Specimens destroyed by corrosion.

b A verage of 2 specimens removed from each site at each pei iod. $t$, Data for 4 specimens.

c + indicates that 1 or more specimens contained holes due to corrosion. 
TABLE 4. Weight losses of pipe specimens of low-alloy cast irons on a relative basis

[Relative to weight loss of plain cast iron $\mathbf{A}=100$ ]

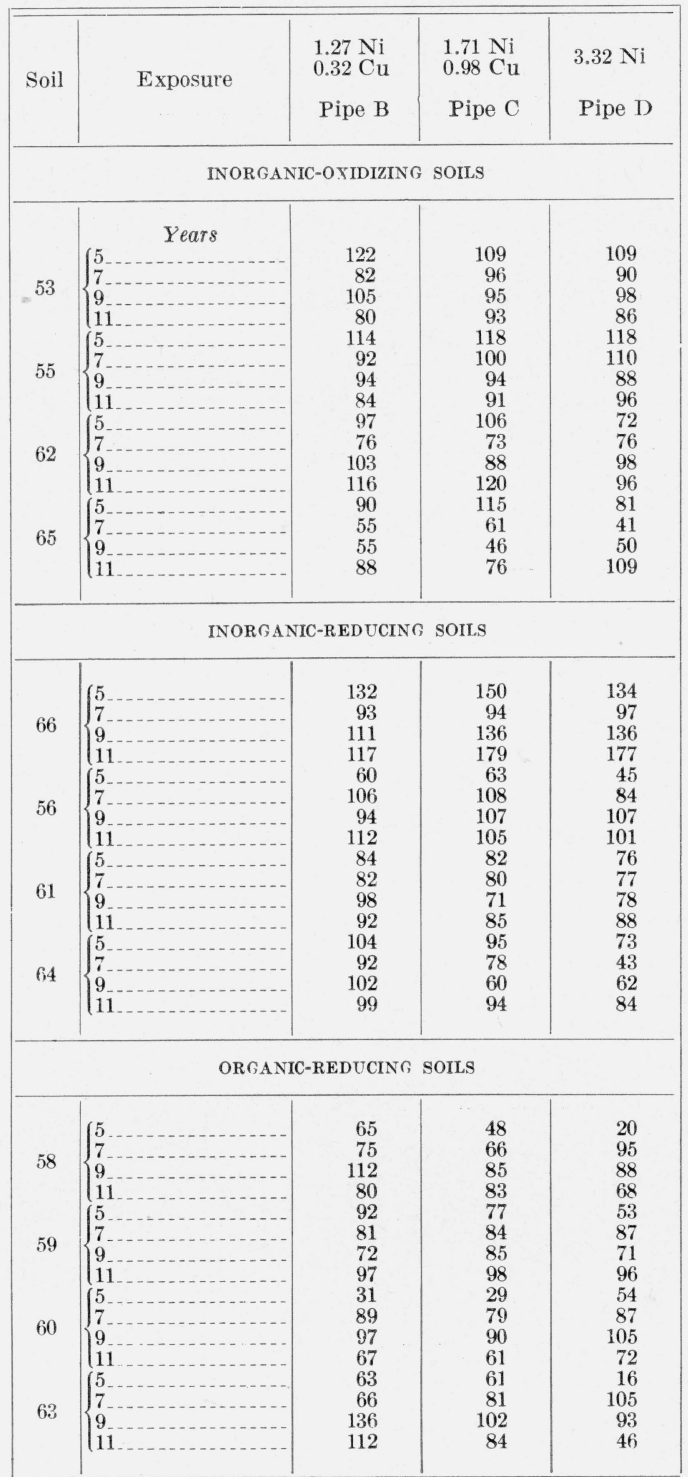


TABLE 5. Hyaraulic bursting pressures and number of perforations of pipe samples

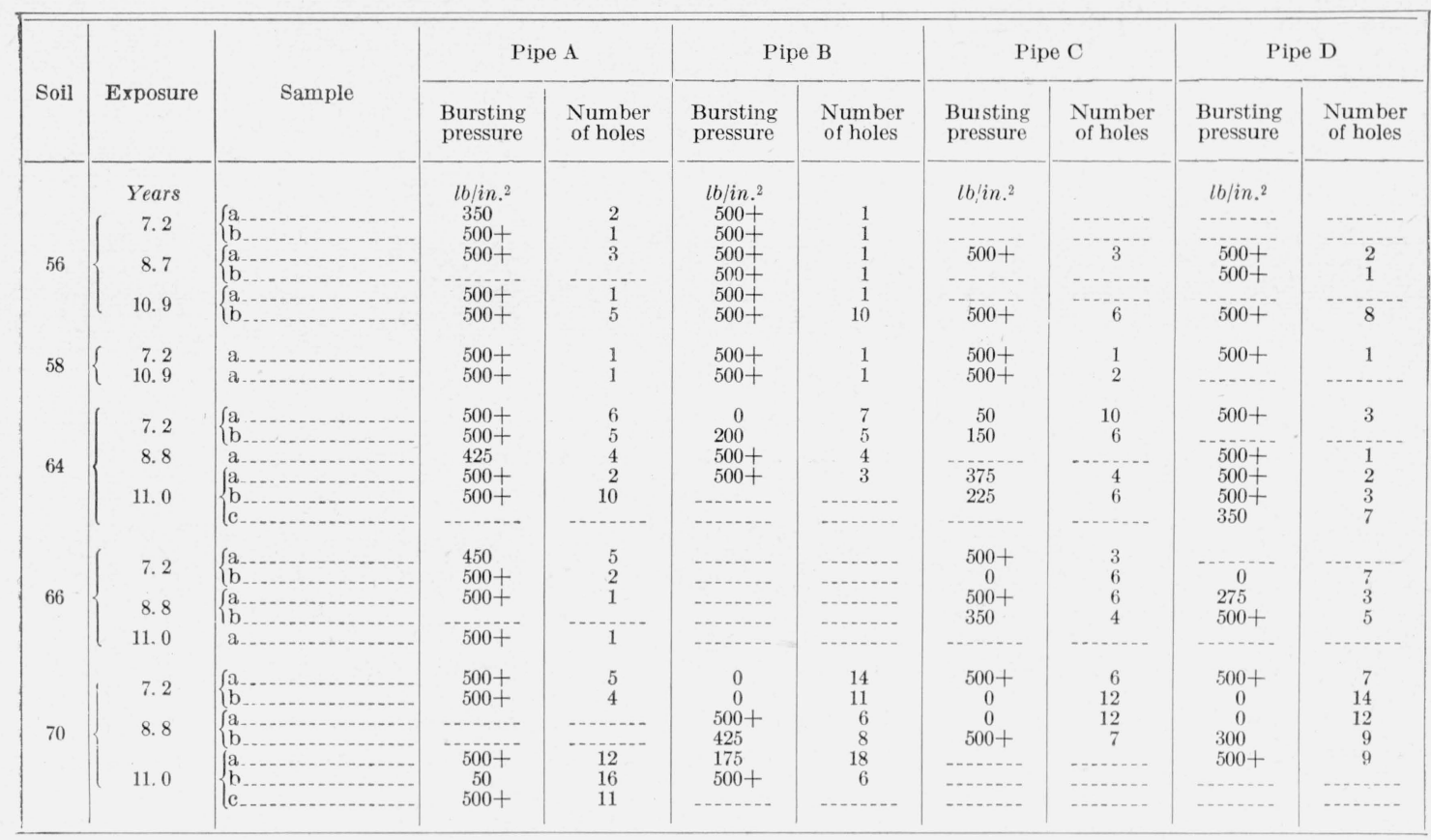

TABLE 6. Condition of cast-iron pipe withstanding a maximum hydraulic pressure of $400 \mathrm{lb} / \mathrm{in}^{2}$

\begin{tabular}{|c|c|c|c|c|c|c|c|}
\hline \multicolumn{2}{|r|}{ Soil } & \multicolumn{4}{|c|}{$\begin{array}{l}\text { Specimens exposed for } \\
\text { measurement of weight } \\
\text { loss and pitting }\end{array}$} & \multicolumn{2}{|c|}{$\begin{array}{l}\text { Specimens } \\
\text { exposed for } \\
\text { application } \\
\text { of hydraulic } \\
\text { pressure of } \\
400 \mathrm{lb} / \text { in. }^{2}\end{array}$} \\
\hline Number & Туре & $\begin{array}{c}\text { Ex- } \\
\text { posure }\end{array}$ & $\begin{array}{l}\text { Wall } \\
\text { thick- } \\
\text { ness }\end{array}$ & $\begin{array}{l}\text { Maxi- } \\
\text { mum } \\
\text { pit } \\
\text { depth }\end{array}$ & $\begin{array}{l}\text { Aver- } \\
\text { age } \\
\text { pene- } \\
\text { tration }\end{array}$ & $\begin{array}{l}\text { Maxi- } \\
\text { mum } \\
\text { period } \\
\text { of ex- } \\
\text { posure }\end{array}$ & $\begin{array}{l}\text { Wall } \\
\text { thick- } \\
\text { ness }\end{array}$ \\
\hline $\begin{array}{l}\text { a15 } \\
64 \\
70(23) \\
\text { a118 }\end{array}$ & $\begin{array}{l}\text { Houston black } \\
\text { clay. } \\
\text { Docas clay } \\
\text { Merced silt loam } \\
\text { Niland gravelly } \\
\text { sand. }\end{array}$ & $\begin{array}{l}\text { Years } \\
17.6 \\
\\
5.0 \\
6.2 \\
5.9\end{array}$ & $\begin{array}{c}\text { Mils } \\
450 \\
\\
250 \\
450 \\
450\end{array}$ & $\begin{array}{l}\text { Mils } \\
226 \\
\\
250+ \\
450+ \\
302\end{array}$ & $\begin{array}{l}30.4 \\
58.4 \\
49.3\end{array}$ & $\begin{array}{l}\text { Years } \\
24 \\
12.5 \\
24 \\
24\end{array}$ & $\begin{array}{l}450 \\
450 \\
450\end{array}$ \\
\hline
\end{tabular}

a See references [2 and 3] for properties of the soils. 

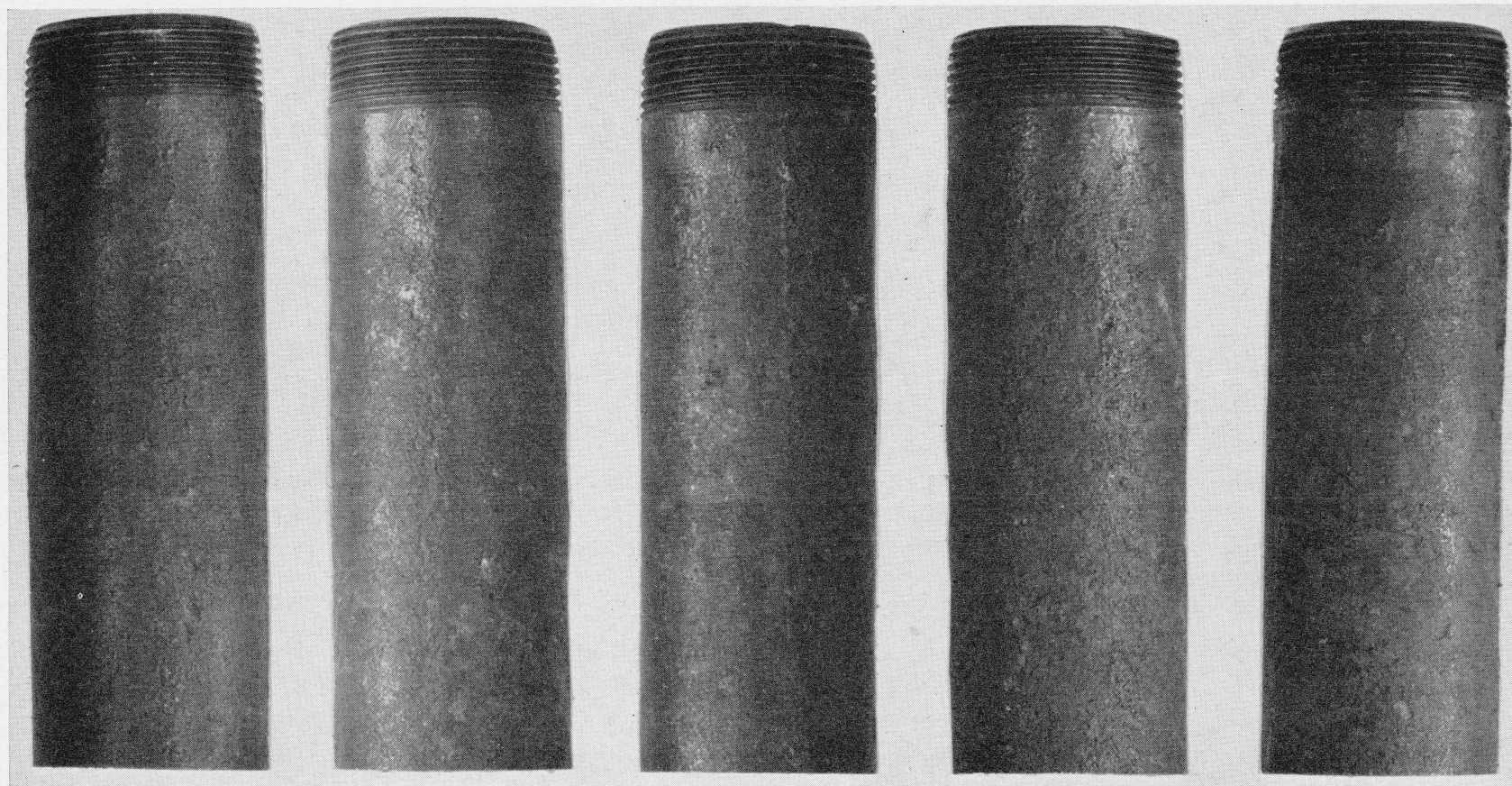

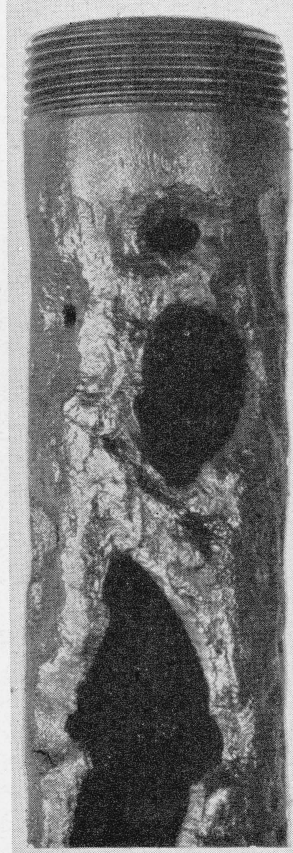

A

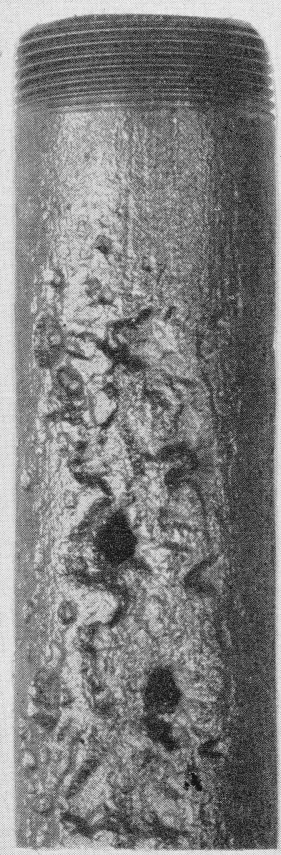

B

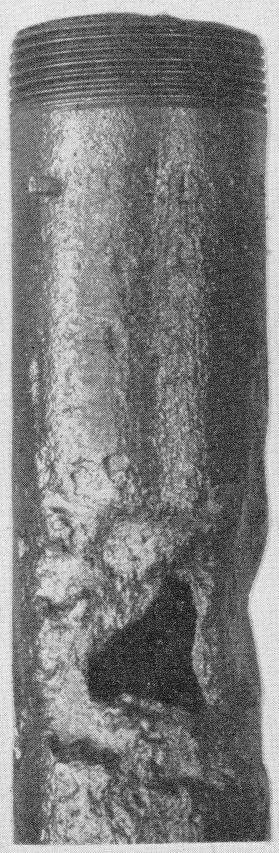

C

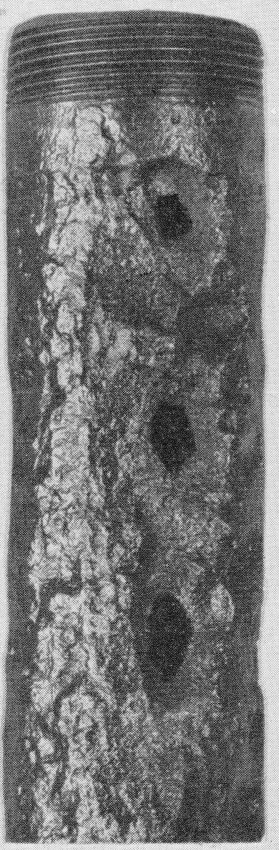

D

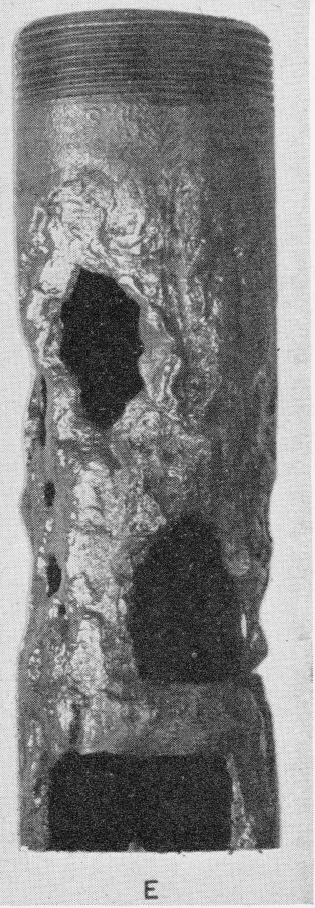

FIGURE 1. Condition of cast iron exposed to highly corrosive soils before (top row) and after (bottom row) removal of the corrosion products.

Exposure 11 years, approximately. A, Lake Charles clay at El Vista, Tex.; B, Muck, at New Orleans, La.; C, Tidal marsh at Charleston, S. C.; D, Docas clay at Cholame, Calif.; E, Merced silt loam at Buttonwillow, Calif.

Washington, August 28, 1953. 